\title{
Dead wood gathering among Neanderthal groups: Charcoal evidence from Abric del Pastor and El Salt (Eastern Iberia)
}

\author{
Paloma Vidal-Matutano ${ }^{\mathrm{a}, \mathrm{b},{ }^{*}, \text { Auréade Henry }}{ }^{\mathrm{b}}$, Isabelle Théry-Parisot ${ }^{\mathrm{b}}$ \\ ${ }^{a}$ PREMEDOC Research Group, Universitat de València, Departament de Prehistòria, Arqueologia i Història Antiga, Blasco Ibáñez 28, 46010, València, Spain \\ ${ }^{\mathrm{b}}$ Université Côte-d'Azur, CEPAM, CNRS, France
}

\section{A R T I C L E I N F O}

Article history:

Received 17 January 2017

Received in revised form

7 March 2017

Accepted 8 March 2017

\section{Keywords:}

Abric del Pastor

El Salt

Middle Palaeolithic

Charcoal analysis

Fuel management

Fungal degradation of wood

\begin{abstract}
A B S T R A C T
We present here a new approach combining the microscopic characterization of fungal decay features and the fragmentation degree of the charcoal remains from Middle Palaeolithic combustion structures: features H4 and H11 from Abric del Pastor, unit IV (>75 ka BP) and features H50 and H57 from El Salt, unit Xb (ca. 52 ka BP), Eastern Iberia. The observation of wood degradation patterns that occurred prior to charring followed by their quantitative analysis according to previous experimental studies revealed differences between the alteration degrees of the firewood used in the hearths, highlighting the existence of firewood acquisition criteria based on dead wood gathering and also suggesting smoke-related functions. Coupled with fragmentation analyses, this method highlighted possible post-depositional processes affecting the higher degraded charcoals. These results lead us to propose a quantitative analysis of the fungal decay patterns on Middle Palaeolithic charcoal reinforcing the previous hypotheses about dead wood gathering among Neanderthal groups as an accessible and available resource in the surroundings. These data have significant implications for the interpretation of firewood use and management by Palaeolithic hunter-gatherers which was traditionally defined as an opportunistic activity according to the absence of selection criteria based on specific taxa.
\end{abstract}

(c) 2017 Elsevier Ltd. All rights reserved.

\section{Introduction}

Anthracology or charcoal analysis traditionally focuses on the botanical identification of charcoal fragments in order to obtain paleoenvironmental data (Badal, 1992; Badal and Heinz, 1989, 1991; Chabal, 1988, 1992; Figueiral, 1992; Thiébault, 1988; Vernet et al., 1983). In this regard, the general ecological coherence of charcoal data from different sites sharing a comparable chrono-geographic frame has been widely understood as the absence of taxonomic selection criteria (Badal et al., 2012; Badal and Carrión, 2001; Ntinou and Kyparissi-Apostolika, 2015). Other authors define prehistoric firewood collecting strategies in terms of cutting green wood or gathering dead wood (Chrzavzez, 2006; Henry and ThéryParisot, 2014; Théry-Parisot, 1998, 2001), which do not forcibly exclude a pronounced taxonomic choice or, on the contrary, the use of a broad spectrum of species (Allué et al., 2016; Henry et al.,

\footnotetext{
* Corresponding author. PREMEDOC Research Group, Universitat de València, Departament de Prehistòria, Arqueologia i Història Antiga, Blasco Ibáñez 28, 46010, València, Spain.

E-mail address: paloma.vidal@uv.es (P. Vidal-Matutano).
}

2009). Although it cannot be used to provide direct inferences about social practices during the Palaeolithic period, ethnoarchaeology provides complementary evidence to propose the hypothesis according to which other selection criteria different from the species may have influenced prehistoric firewood gathering activities. Indeed, ethnoarchaeological studies reveal the existence of planned activities mostly oriented towards the calibre and the state of the wood: healthy, green, dry, dead and rotten wood (Alix and Brewster, 2004; Henry et al., 2009; Henry and Théry-Parisot, 2014).

So far, the available data on firewood use and management by Neanderthal groups remain very scarce and only a very few studies draw attention to the socio-economic implications linked to fuel use i.e., the existence of firewood selection criteria as well as the use of alternate fuels. Indeed, first use of coal or lignite was documented during the Mousterian at Les Canalettes (Southern France, MIS 3), which may have involved specialized activities implicating high energetic needs (Théry-Parisot et al., 1996; Théry-Parisot and Meignen, 2000). Other studies involving the observation of microscopic degradation features on charcoal suggest that Middle Palaeolithic groups relied on dead wood as a fuel (Chrzavzez, 2006; 
Théry-Parisot and Texier, 2006). At La Combette (Southern France, MIS 3), the use of degraded wood is interpreted as a practice related to specific hearth functions linked to meat processing. At Fumane (Northern Italy, MIS 3), the use of dead wood was supported by the observation of wood degradation patterns but also by wood diameter estimations pointing towards the use of small calibres, consistent with the practice of dead wood gathering. While it was interpreted in this case as related to changes in the firewood supply area, this practice can more generally be linked to short occupations and greater mobility of human groups (Chrzazvez et al., 2011; Théry-Parisot et al., 2016).

With the aim of obtaining significant palaeoeconomical data in terms of wood selection criteria, we present the results of a study geared toward the identification of firewood gathering behaviour of Neanderthal groups in Eastern Iberia based on anthracological data from several combustion features. With this purpose, we adopt a taphonomic approach based on the fact that human practices by wood collecting and hearth management (human choices, preferences and actions) appear as the first filter conditioning charcoal assemblages (Théry-Parisot et al., 2010). Thus, the development of ways of characterizing the gathering/cutting practices via the recognition of wood anatomical signatures is crucial to our better understanding of this first, societal, filter. The aim of this paper is to characterize firewood use and management by Neanderthal groups from two sites located in Eastern Iberia, El Salt and Abric del Pastor. Our goals with this study have been: 1) To assess the appropriateness of Middle Palaeolithic combustion features for implementing the existing analytical methodologies and 2) To provide new anthracological data from archaeological contexts which can contribute to reach a more holistic understanding of firewood use and hearth function.

\section{Middle Palaeolithic charcoal assemblages}

The standard conception of a well preserved in situ flat Middle Palaeolithic combustion structure consists in a microstratigraphy sequence made up of a reddish-brown layer at the base, overlain by a dark brown/black layer and capped by a white/yellowish or pinkish white layer (Mallol et al., 2013b). However, most of these features are postdepositionally affected by erosion, weathering and diagenesis causing the complete or partial loss of the ashy layer. This entails significant consequences as in most of the cases the black layer (the thermoaltered topsoil) is considered the main layer representative of the combustion event from which firewood management practices are often deduced.

Keeping in mind that charcoal from Middle Palaeolithic combustion structures is rarely preserved, traditional charcoal analyses have focused on scattered assemblages providing meaningful palaeoenvironmental data. Indeed, according to the standardized anthracological premises, scattered charcoal spread over human living surfaces is the result of several combustion events. As an average representation of cumulative processes resulting from an undefined number of occupation events, scattered charcoal fragments are mostly representative of the environment but difficult to link to a particular practice while charcoal remains from combustion features would represent a more accurate time record, offering an instantaneous picture of the last firewood collecting actions in the supply area (Badal and Heinz, 1991; Chabal, 1997). In order to work on human practices, we thus carefully selected combustion features from each site as the most suitable charcoal deposits for this study.

Over the past years, several methods have allowed to go beyond the palaeobotanical information of charcoal aiming towards the recognition of the initial state and calibre of the wood. They rely on the microscopic analysis of anatomical signatures (radial cracks, fungal degradations, vitrification) and on mathematical models aiming at reconstructing the initial diameters of the firewood used (e.g. Dufraisse, 2006; Marguerie and Hunot, 2007). However, not all charcoal assemblages allow palaeoeconomical inferences due to the sample size, the nature of the charcoal (scattered/concentrated assemblages) or their preservation degree. At El Salt and Abric del Pastor, charcoal from four concentrated assemblages was abundant and well preserved enough (Vidal-Matutano, 2016a; VidalMatutano et al., 2015) to carry out this pilot study testing new methods on the observation of fungal degradation features. Nevertheless, the high fragmentation degree of charcoal hampered wood diameter estimations whereas vitrified fragments -the homogenization of some anatomical elements - was only present to a much lesser extent $(<2 \%)$ and is thus not discussed here.

Since it can provide data about firewood acquisition strategies by past human groups, the identification of the state of the wood used as firewood in our combustion structures is an important challenge. Wood may be attacked by fungi and insects while still alive or already dead as the cell walls of woody plants are a source of nutrition for a variety of different pathogens (bacteria, fungi and xylophage insects). These attack the lignin, cellulose and hemicellulose, thus reducing the thickness of the cell wall and therefore its strength (Baldrian and Valášková, 2008; Blanchette, 1991; Leonowicz et al., 1999; Tuor et al., 1995). At a microscopic level -relevant to anthracology-fungal hyphae penetrating the fibres or the tracheids as well as the anatomical alterations within the wood are preserved after charring (Allué et al., 2012; Badal et al., 2012; Carrión and Badal, 2004; Moskal del Hoyo et al., 2010; VidalMatutano et al., 2015). Recent studies dealing with fungal degradation patterns on charcoal evidenced statistically significant differences between charcoal assemblages composed of healthy wood, dead wood and rotten wood, expressed through the proportions of different alteration levels (A.L.) and an Alteration index $(A i)$, showing that different states of wood can only be discriminated through a quantitative approach (Henry, 2011; Henry and Théry-Parisot, 2014). These last assemblages are used here as a basic reference to the understanding of the significance of the Alteration index values from the Middle Palaeolithic combustion features presented in this work.

In addition, anthracologists have tried to understand if species did fragment differentially and how the charcoal record could be affected by fragmentation. Experimental studies have shown that wood charcoals degraded by fungi are more susceptible to postdepositional mechanical damage (Théry-Parisot, 2001; ThéryParisot et al., 2010). According to this, mechanical processes (trampling, reworking, biological activity, freeze/thaw or dry/humidity cycles) can lead to the hyper-fragmentation of charcoal, thus affecting our perception regarding charcoal abundance in some Palaeolithic sites (Théry-Parisot et al., 2010). The statistical analysis of different size-classes from Le Marduel and Lattara (France) by Chabal $(1992,1997)$ and from Cova de les Cendres (Spain) by Badal (1988) showed that all taxa have a similar fragmentation pattern. More recent experimental studies on modern Pinus sylvestris wood have evidenced the effect of mechanical processes on charcoal considering the state of the wood before combustion: carbonized healthy wood was three to five times more resistant than carbonized degraded wood (Chrzazvez et al., 2014; Théry-Parisot et al., 2010). Thus, through wood acquisition modalities, human decision-making would have a decisive impact on charcoal preservation, hampering the possibility of recognizing strategies based on dead wood gathering. However, the nature and intensity of postdepositional factors (e.g., sedimentation rate) remain the most important variables determining the preservation degree of the combustion features (Mallol et al., 2007) and the charcoal deposit (Chrzazvez et al., 2014). Hence, the high potential of 
micromorphological analyses to reconstruct the history of combustion features and to estimate their preservation degree has been widely demonstrated (e.g. Goldberg et al., 2012).

\section{Regional setting and excavation methodology}

\subsection{Overview of the sites}

Abric del Pastor is a small rock-shelter $\left(60 \mathrm{~m}^{2}\right)$ facing north-east. It is located in the Mariola Mountains of Alcoy, Alicante, on the right bank of the Barranc del Cinc gorge, at $820 \mathrm{~m}$ a.s.l. (Fig. 1). This highland region is characterized by numerous valleys and natural corridors. The site is an eroded karstic paleotube belonging to a larger karstic network linked to the phreatic activity of the Serpis River. The first archaeological excavations in the rock-shelter were carried out by M. Brotons in 1953 affecting the upper part of the deposit (about $50 \mathrm{~cm}$ ). Current excavations, ongoing since 2005, have yielded new contextualized data covering an area of $42 \mathrm{~m}^{2}$ (Hernández et al., 2014; Machado et al., 2013; Vidal-Matutano, 2015; Vidal-Matutano et al., 2015). The sedimentary sequence known to date is $1.5 \mathrm{~m}$ thick and has been divided into six stratigraphic units, according to macroscopic and micromorphological sedimentological criteria. TL dates from S.U. IV (70 cm thick) indicate that this unit is older than $75 \mathrm{ky} . \pm 10,000$ (N. Mercier, pers. comm.) and it has been identified over the entire excavated area comprising an alternation of cobble beds (IVa, IVc, IVe and IVg) and finer-grained sandy-gravelly layers (IVb, IVd and IVf). These subunits are the result of the palimpsest dissection analysis aiming at the identification of single human occupations with the intervention of the geoarchaeological study of the sedimentary facies, spatial analysis, faunal and lithics refitting and the distribution of fuel remains. Palaeoecological data from the scattered assemblage of S.U. IV indicated the prevalence of dry/semi-arid supramediterranean conditions (mean annual temperature or MAT between 8 and $13{ }^{\circ} \mathrm{C}$ and mean annual precipitation or MAP between 200 and $600 \mathrm{~mm}$ ) considering the high values of junipers (VidalMatutano et al., 2015).

The site of El Salt is an open-air rock shelter located at $680 \mathrm{~m}$ a.s.l. and approximately $4 \mathrm{~km}$ South from Abric del Pastor (Fig. 1). The Middle Palaeolithic sequence is represented by eight stratigraphic units dating between $60.7 \pm 8.9$ and $45.2 \pm 3.4 \mathrm{ka} \mathrm{BP}$ (Galván et al., 2014). A Paleocene limestone wall $38 \mathrm{~m}$ in height formed at a thrust fault and covered with tufa and travertine protected the space occupied by humans at the bottom of the wall, which at times of maximum development covered almost the entire excavated surface. This deposit has been systematically excavated since 1986 with an integrated multidisciplinary approach based on obtaining higher temporal resolutions for the analysis related to Neanderthal behaviour (Galván et al., 2014; Garralda et al., 2014; Machado and Pérez, 2015; Mallol et al., 2013a, 2013b; Rodríguez-Cintas and Cabanes, 2015; Sistiaga et al., 2014; Vidal-Matutano, 2016a). The archaeo-sedimentary deposit included in the lower part of the stratigraphic sequence consists of a dense palimpsest originating from recurrent human occupations during which several activities were developed corresponding to the generic model of "hearth-related assemblages" (Vaquero and Pastó, 2001) i.e., superimposed flat combustion features of various sizes (0.20-1 m diameter) associated with rich archaeological assemblages including faunal remains, lithic objects, limestone pebbles with use-wear and wood-charcoal fragments. Excavation of S.U. Xb has allowed the identification of an initial division of the palimpsest deposit into several fine-grained analytical units designated Archaeosedimentary Facies Associations (henceforth, AFA). These units correspond to the highest possible

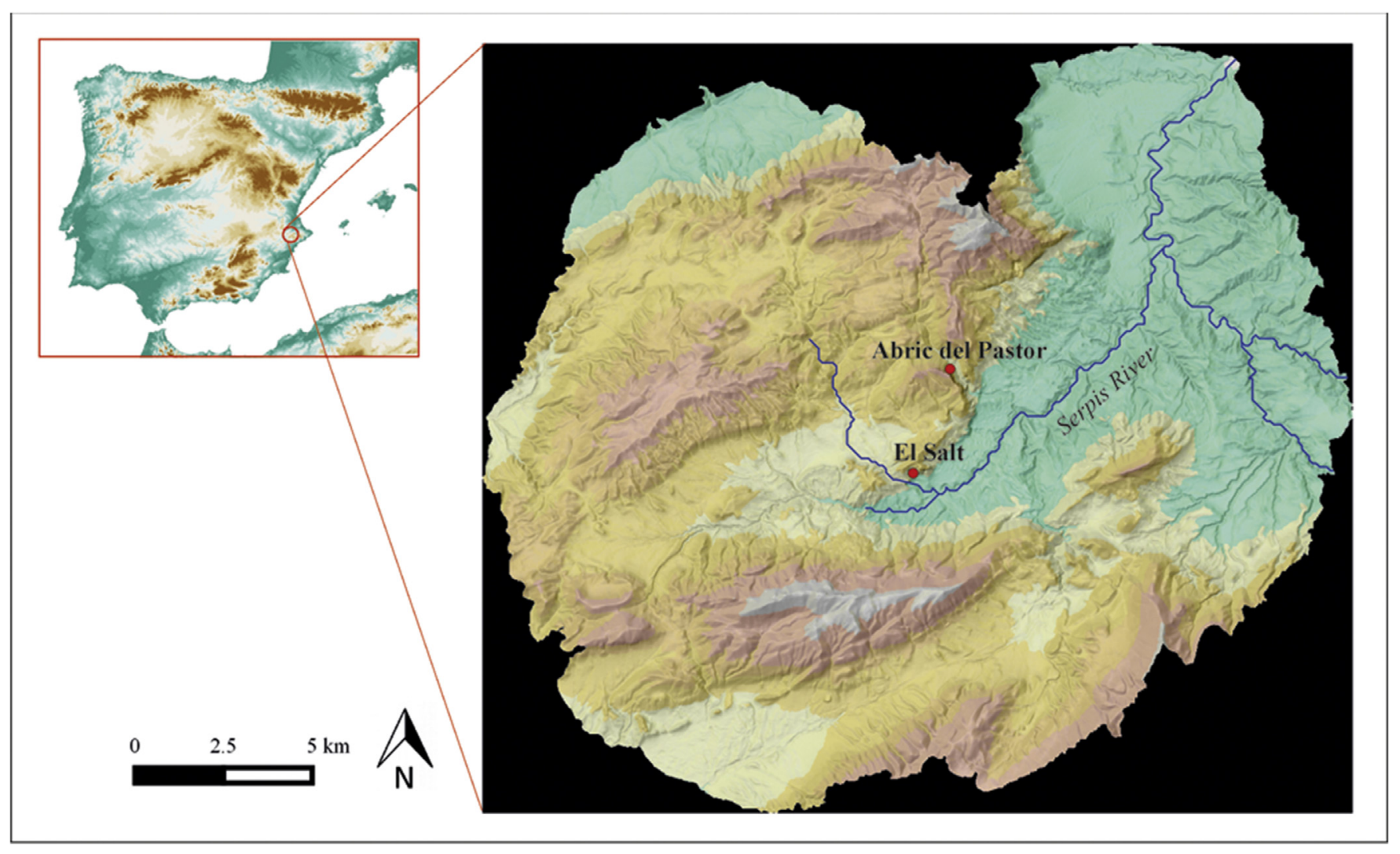

Fig. 1. Geographic location of the Middle Palaeolithic sites of Abric del Pastor and El Salt in Iberia and the Prebaetic System. 
temporal resolution achievable within the context studied (Machado et al., 2016; Machado and Pérez, 2015). Palaeoecological data from S.U. Xb point out to a local landscape characterized by the prevalence of sub-humid supramediterranean conditions (MAT 8-13 ${ }^{\circ} \mathrm{C}$ and MAP 600-1000 mm) (Vidal-Matutano, 2016a, 2016b).

\subsection{Selection of the combustion features}

In order to carry out the analysis of the anatomical alterations caused by fungal activity on wood prior to combustion, we selected two combustion features from each site as the most suitable charcoal deposits for this study: features H4 (subunit IVc2) and H11 (subunit IVd3) from Abric del Pastor and white or ashy layers from features H57 (AFA 2) and H50 (AFA 3) from El Salt. The decision to study these combustion structures from a palaeoeconomical approach was made in the light of the nature of the charcoal remains and the microstratigraphy of some of the hearths. Thus, the microstratigraphy of H50 and H57 from El Salt is composed of a thick layer of white ash and a black layer of carbonized organic residue at the base of the feature formed by prior activities (Mallol et al., 2013b). As Middle Palaeolithic combustion features typically exhibit post-depositional disturbances including human reworking, erosion and/or weathering (Albert et al., 2012; Goldberg et al., 2012), these features are an exception to this expectation with suitable anthracological samples from the ashy layer. Additionally, these four anthracological assemblages contain close to 100 wood charcoal fragments enabling the comparative study as saturation curves from previous experimental studies have shown (Henry and Théry-Parisot, 2014). In this sense, some prerequisites might be needed to obtain significant palaeoeconomical contributions regarding firewood management and fire-related practices, e. g. exhaustive micromorphological analyses of the features' sequences, charcoal analyses focused on the white/ashy layers containing the last firewood residues, systematic sampling for wet sieving process and the recovery of a sufficient amount of charcoal fragments.

Hearths H4 and H11 from Abric del Pastor were found stratigraphically overlapping on the periphery below the current dripline. Hearth $\mathrm{H} 11$ is older than $\mathrm{H} 4$ and was located on top of a layer of burned stones. These combustion features were identified during the fieldwork on the basis of thermal alteration of the substrate, either rocky or sandy depending on the lithostratigraphic unit to which they belong. According to micromorphology and FTIR data the ashes are only preserved in a relict way (Mallol et al., 2013b). At El Salt, hearth $\mathrm{H} 50$ was circular in shape with the ashy layer located in the middle of the feature presenting an irregular perimeter, while the black layer was unusually thick $(6 \mathrm{~cm})$ with a greasy aspect and a greyish hue. Hearth $\mathrm{H} 57$ was located close to the wall of the rock shelter and consisted of a small ashy layer and a black one that surrounded the central area. It should be noted that part of this hearth was affected by the excavations carried out in the 1960s and, therefore, some of its sediment might have been lost. Despite the reduced nature of the white layer it provided interesting macrobotanical evidence, a quite important amount of charcoal but also 253 charred maple seeds (G. Perez pers. comm).

\section{Material and methods}

\subsection{Sampling method, charcoal analysis and reference collections}

During the 2013 and 2014 archaeological field seasons, systematic soil sampling of the entire excavated surface from both sites was conducted for water flotation to separate macrobotanical remains from sediments using meshes of 1 and $0.2 \mathrm{~mm}$ (VidalMatutano, 2016b). Each charcoal fragment was fractured manually to provide transverse, tangential and radial sections for taxonomic identification using a Nikon Optiphot-100 bright/darkfield incident light microscope with 50-500× magnification. Botanical identification was performed with specialized plant anatomy atlases (Jacquiot et al., 1973; Schweingruber, 1976) as well as the reference collection of modern charred woody taxa from the Department of Prehistory, Archaeology and Ancient History, University of Valencia.

Access to reference collections was also essential to compare the anatomical alterations observed and to establish the degree of alteration in each fragment. Such reference collections were available at the CEPAM Archaeobotany Laboratory (CNRS) and consisted in datasets from previous experimental studies (Henry, 2011; Henry and Théry-Parisot, 2014; Théry-Parisot, 1998, 2001).

\subsection{Microscopic observation protocol}

The transverse and tangential sections of each charcoal fragment available for taphonomic analysis were observed using a Leica DM LM reflection microscope and a video camera connected to a computer equipped with LAS Image Analysis v.4.4 software. It should be stressed out that in some cases, fungal decay features could not be observed due to the reduced size of the material (especially $<1 \mathrm{~mm}$ size-class) or its preservation degree. Despite of this, the four anthracological assemblages provided sufficient quantity of suitable charcoal fragments to carry out the taphonomic analysis. Our protocol was also designed to take into account the different anatomical structure of angiosperms and gymnosperms, while the quantitative analysis of fungal degradations was only applied to conifers.

\subsubsection{Fungi}

The characterization of fungal degradation patterns on softwoods (conifers) was defined in accordance with Henry and ThéryParisot (2014), based on the recognition of four Alteration Levels (A.L.): no alteration (A.L. 0), low alteration (A.L. 1), medium alteration (A.L. 2) and high alteration (A.L. 3). These A.L. were defined on the basis of the stages of fungal colonization and degradation of wood (e.g., Schwarze, 2007). At an incipient stage of biodegradation, the cell walls show perforations while the increasing depolymerisation of wood through the loss of cellulose, lignin or both leads to cellular deformation and eventually, collapse (Fig. 2a). Quantitative analyses of the A.L. of ten experimental fires of Pinus sylvestris and two ethnographic samples of Larix cajanderi in different states (from healthy, oven-dried wood, to crumbling, rotten wood) showed that high degradation features (A.L. 2 and 3) were present even in healthy wood (batches $\mathrm{H} 1$ and $\mathrm{H} 2$ ), confirming the fact that biodegradation can take place also in sound, living wood (Théry-Parisot, 2001). But more importantly, the experiments showed that while there can be infinite variations, reflecting the very progressive nature of fungal degradation occurring at a microscopic level, the proportions between the different A.L. and their correlation with the macroscopic state of the wood are however, highly significant (Fig. 2c). While it is very difficult to discriminate lying (LD) from standing dead wood (SD) since they are included within the same range of macroscopic characteristics, healthy $(H)$ and decayed $(R, N)$ wood were respectively characterized by 1 ) extremely low percentages of A.L. 2 and 3 with high percentages of A.L. 0; and 2) very low percentages of A.L. 1 with high percentages of A.L. 2 and 3. (Fig. 2c). In order to assess the homogeneity of each archaeological sample, saturation curves were used taken into account the percentages of the different A.L. per number of identified fragments (Henry and Théry-Parisot, 2014). These are regression curves traditionally used in charcoal analysis to indicate the optimal number of charcoal fragments to be 
a. Characterization of fungal degradation patterns: Alteration Levels (Henry and Théry-Parisot 2014)

GYMNOSPERMS (Pinus nigra-sylvestris from A. del Pastor and El Salt. a-d: x400, e: x5000, f: x4000; g-h: x1500)

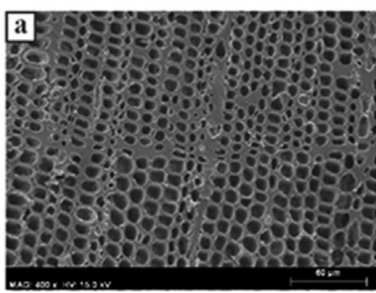

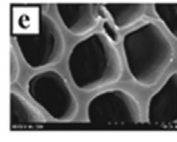

A.L. 0

No sign of micromorphological changes in its anatomy.
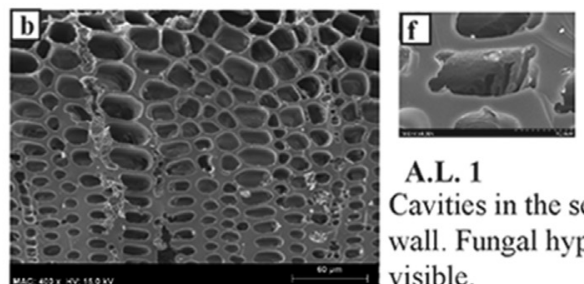

A.L. 1

Cavities in the secondary wall. Fungal hyphae often visible.
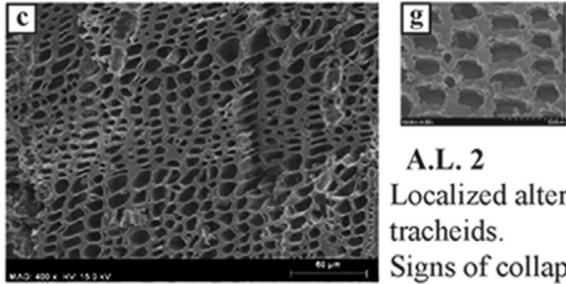

A.L. 2

Localized alteration of some tracheids.

Signs of collapsed cells
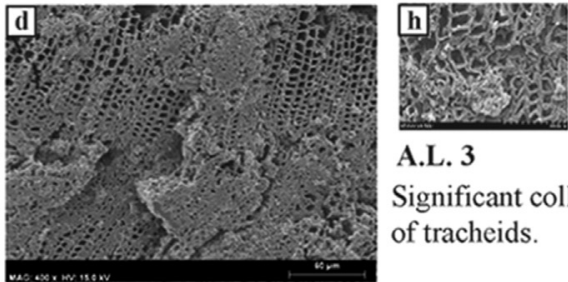

A.L. 3

Significant collapse of tracheids.

ANGIOSPERMS (Acer sp. from El Salt. a-b: x400)

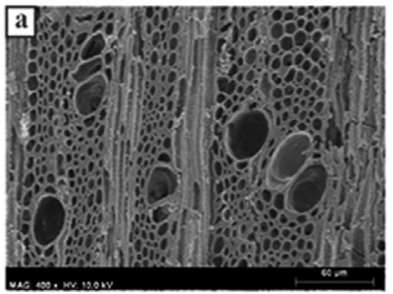

\section{A.L. 0}

No sign of micromorphological changes in its anatomy.

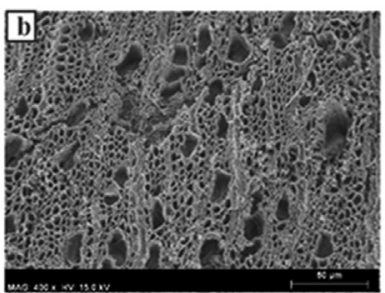

\section{A.L. 1}

Degraded cell walls Spongy appearance

b. Calculation of the relative frequencies and the Alteration Index (Henry and Théry-Parisot 2014)

$$
A i=((\mathrm{nA} 1 \times 1+\mathrm{nA} 2 \times 2+\mathrm{nA} 3 \times 3) / \mathrm{nTOT} \times 3)
$$

c. Experimental samples (Henry and Théry-Parisot 2014)

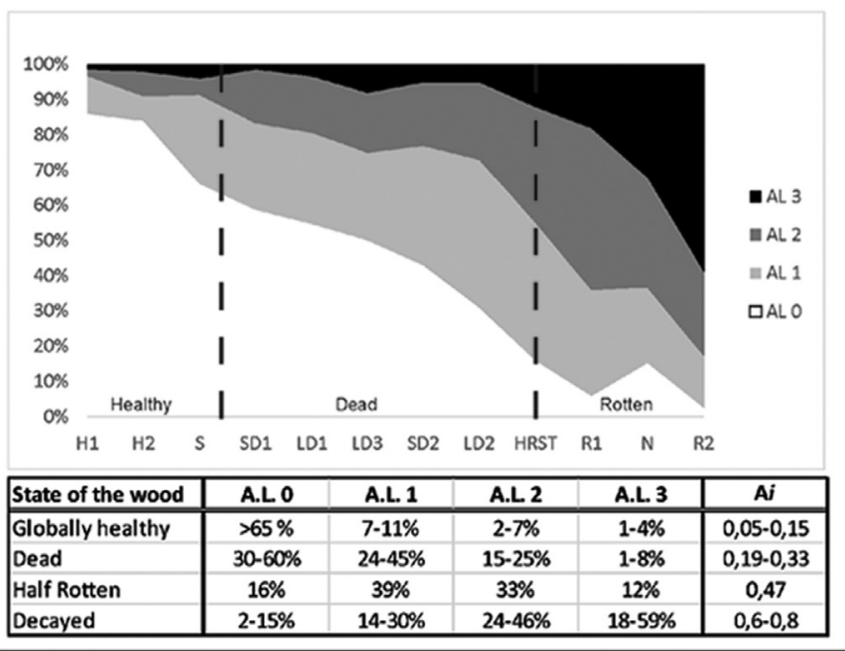

Fig. 2. Methodology. a: Characterization criteria for fungal anatomical alterations; b: Alteration Index; c: experimental reference frame. 
taken into account for obtaining a floristically representative sample (Chabal, 1997). The results for each sample (combustion feature) were compared to the experimental reference samples through a statistical test of multiple pairwise comparisons. The calculation of the Alteration Index $(A i)$ synthesizes the A.L. proportions compared to the total number of degraded charcoal fragments (Fig. 2b). It is a quantitative measure allowing to assess the initial macroscopic state of the wood, which has to be completed by the examination of the A.L. percentages distribution per sample (Henry and Théry-Parisot, 2014).

Although decay features are well-characterized and wellrecognised in anthracology also on angiosperms (Henry, 2011; Moskal del Hoyo et al., 2010; Théry-Parisot, 2001), no experimental work allowing to interpret the macroscopic state of the wood on the basis of a charcoal assemblage is yet available for the taxa identified at both sites (Acer sp. and Pistacia sp.). Thus, we recorded cellular degradation patterns on angiosperms by a binomial, presence (A.L. 1) or absence (A.L. 0) system.

\subsubsection{Fragmentation degree}

Each flotation sample was separated into four size-classes with meshes ranging from $>4 \mathrm{~mm}, 2-4 \mathrm{~mm}, 1-2 \mathrm{~mm}$ and $<1 \mathrm{~mm}$ in order to analyse the fragmentation degree for each combustion feature and A.L.

\section{Results}

\subsection{Palaeobotanical data and fragmentation degree}

Charcoal analysis from the combustion features was applied to all wood charcoal fragments recovered from the flotation of the sediments (Table 1). The botanical content of the combustion features from Abric del Pastor ( $\mathrm{H} 4$ and $\mathrm{H} 11$ ) indicates the dominance of two taxa, Juniperus sp. -junipers- and Pistacia sp. -terebinth/ mastic-, both of which also dominate the scattered contexts from the lithostratigraphic units to which the combustion features belong (Vidal-Matutano et al., 2015). Additionally, other taxa such as Quercus spp./Quercus spp. evergreen (evergreen oaks), Rosa sp. (the Rose gender), Taxus baccata (yew) or Cistaceae (rockroses) were occasionally identified.

Botanical identification of charcoal fragments from the ashy layers of El Salt combustion structures (H50 and H57) also reflects the firewood gathering of two main taxa: Pinus nigra-sylvestris (black-scots pine) and Acer sp. (maple) (Table 1). Other taxa such as Buxus sempervirens (boxwood) or Quercus spp. (oak) are also occasionally present.

The analysis of the fragmentation degree of each feature evidenced a general distribution of charcoal fragments within two

Table 2

Quantification analysis for the angiosperm charcoal fragments from the combustion features.

\begin{tabular}{|c|c|c|c|c|c|c|c|c|}
\hline \multirow{3}{*}{$\frac{\text { Site }}{\text { Combustion feature }}$} & \multicolumn{4}{|c|}{ Abric del Pastor } & \multicolumn{4}{|c|}{ El Salt } \\
\hline & \multicolumn{2}{|c|}{$\mathrm{H} 4$} & \multicolumn{2}{|c|}{ H11 } & \multicolumn{2}{|c|}{$\mathrm{H} 50$} & \multicolumn{2}{|c|}{ H57 } \\
\hline & $\mathrm{N}$ & $\%$ & $\mathrm{~N}$ & $\%$ & $\mathrm{~N}$ & $\%$ & $\mathrm{~N}$ & $\%$ \\
\hline 0 & 9 & 10.34 & 12 & 22.22 & 23 & 32.39 & 6 & 26.09 \\
\hline 1 & 78 & 89.66 & 42 & 77.78 & 48 & 67.61 & 17 & 73.91 \\
\hline Total charcoal & 87 & 100 & 54 & 100 & 71 & 100 & 23 & 100 \\
\hline
\end{tabular}

Table 1

Anthracological data from the combustion features and the scattered assemblages (W.L. = White or ashy layer)

\begin{tabular}{|c|c|c|c|c|c|c|c|c|c|c|c|c|c|c|c|c|}
\hline \multirow{4}{*}{$\begin{array}{l}\text { Site } \\
\text { Unit } \\
\text { Charcoal context } \\
\text { Taxa }\end{array}$} & \multicolumn{8}{|c|}{ Abric del Pastor } & \multicolumn{8}{|l|}{ El Salt } \\
\hline & \multicolumn{4}{|l|}{ IVc2 } & \multicolumn{4}{|l|}{ IVd3 } & \multicolumn{4}{|l|}{ AFA 2} & \multicolumn{4}{|c|}{ AFA 3} \\
\hline & \multicolumn{2}{|c|}{ Scattered } & \multicolumn{2}{|l|}{$\mathrm{H} 4$} & \multicolumn{2}{|c|}{ Scattered } & \multicolumn{2}{|l|}{ H11 } & \multicolumn{2}{|c|}{ Scattered } & \multicolumn{2}{|c|}{ H57 (W.L.) } & \multicolumn{2}{|c|}{ Scattered } & \multicolumn{2}{|c|}{ H50 (W.L.) } \\
\hline & $\mathrm{N}$ & $\%$ & $\mathrm{~N}$ & $\%$ & $\mathrm{~N}$ & $\%$ & $\mathrm{~N}$ & $\%$ & $\mathrm{~N}$ & $\%$ & $\mathrm{~N}$ & $\%$ & $\mathrm{~N}$ & $\%$ & $\mathrm{~N}$ & $\%$ \\
\hline Angiosperm & 26 & 8.31 & 9 & 4.48 & 17 & 14.66 & 25 & 16.13 & 24 & 1.50 & & & 12 & 1.55 & & \\
\hline Acer sp. & & & & & & & & & 110 & 6.88 & 19 & 4.79 & 148 & 19.17 & 63 & 39.87 \\
\hline cf Acer sp. & & & & & & & & & 2 & 0.13 & & & 5 & 0.65 & 3 & 1.90 \\
\hline Buxus sempervirens & & & & & & & & & 20 & 1.25 & 2 & 0.50 & 12 & 1.55 & 2 & 1.27 \\
\hline Cistaceae & 1 & 0.32 & 2 & 1.00 & & & & & & & & & & & & \\
\hline Conifers & 15 & 4.79 & 6 & 2.99 & 8 & 6.90 & 18 & 11.61 & 51 & 3.19 & 8 & 2.02 & 21 & 2.72 & 3 & 1.90 \\
\hline Ephedra sp. & 5 & 1.60 & & & & & & & & & & & 1 & 0.13 & & \\
\hline Euphorbiaceae & 4 & 1.28 & & & & & & & & & & & & & & \\
\hline Fabaceae & 5 & 1.60 & & & 7 & 6.03 & & & 7 & 0.44 & & & & & & \\
\hline Ficus carica & & & & & 1 & 0.86 & & & 4 & 0.25 & & & & & & \\
\hline Fraxinus sp. & 1 & 0.32 & & & 5 & 4.31 & & & & & & & & & & \\
\hline Hedera sp. & & & & & & & & & 5 & 0.31 & & & & & & \\
\hline Juniperus sp. & 7 & 2.24 & 101 & 50.25 & 21 & 18.10 & 76 & 49.03 & 16 & 1.00 & & & 3 & 0.39 & & \\
\hline cf Juniperus sp. & 138 & 44.09 & & & 7 & 6.03 & 1 & 0.65 & & & & & & & & \\
\hline Labiatae & 7 & 2.24 & & & & & & & & & & & & & & \\
\hline Maloideae & 3 & 0.96 & & & & & & & & & & & & & & \\
\hline Monocotyledoneae tp. Poaceae & 1 & 0.32 & & & & & & & & & & & & & & \\
\hline Pinus nigra-sylvestris & 4 & 1.28 & & & 8 & 6.90 & 5 & 3.23 & 1324 & 82.80 & 113 & 28.46 & 549 & 71.11 & 84 & 53.16 \\
\hline Pistacia sp. & 34 & 10.86 & 60 & 29.85 & 7 & 6.03 & 19 & 12.26 & 1 & 0.06 & & & & & & \\
\hline cf Pistacia sp. & 5 & 1.60 & 16 & 7.96 & 1 & 0.86 & 7 & 4.52 & 1 & 0.06 & & & & & & \\
\hline Quercus spp. & 10 & 3.19 & & & 9 & 7.76 & 1 & 0.65 & 25 & 1.56 & 2 & 0.50 & 20 & 2.59 & 3 & 1.90 \\
\hline Quercus deciduous & & & & & & & & & 1 & 0.06 & & & & & & \\
\hline Quercus evergreen & 41 & 13.10 & & & 14 & 12.07 & 1 & 0.65 & 3 & 0.19 & & & 1 & 0.13 & & \\
\hline Rosa sp. & & & 7 & 3.48 & & & 1 & 0.65 & & & & & & & & \\
\hline Salix-Populus & 2 & 0.64 & & & 7 & 6.03 & & & 4 & 0.25 & & & & & & \\
\hline Taxus baccata & & & & & 4 & 3.45 & 1 & 0.65 & & & & & & & & \\
\hline Ulmaceae & 4 & 1.28 & & & & & & & 1 & 0.06 & & & & & & \\
\hline cf Acer sp. seeds & & & & & & & & & & & 253 & 63.73 & & & & \\
\hline Volume sediment in litres & 45 & & 3.5 & & 31.5 & & 4 & & 291.7 & & 2 & & 305 & & 4.5 & \\
\hline Total charcoal & 313 & 100 & 201 & 100 & 116 & 100 & 155 & 100 & 1599 & 100 & 144 & 100 & 772 & 100 & 158 & 100 \\
\hline Total taxa & 14 & & 4 & & 9 & & 6 & & 12 & & 4 & & 6 & & 4 & \\
\hline
\end{tabular}




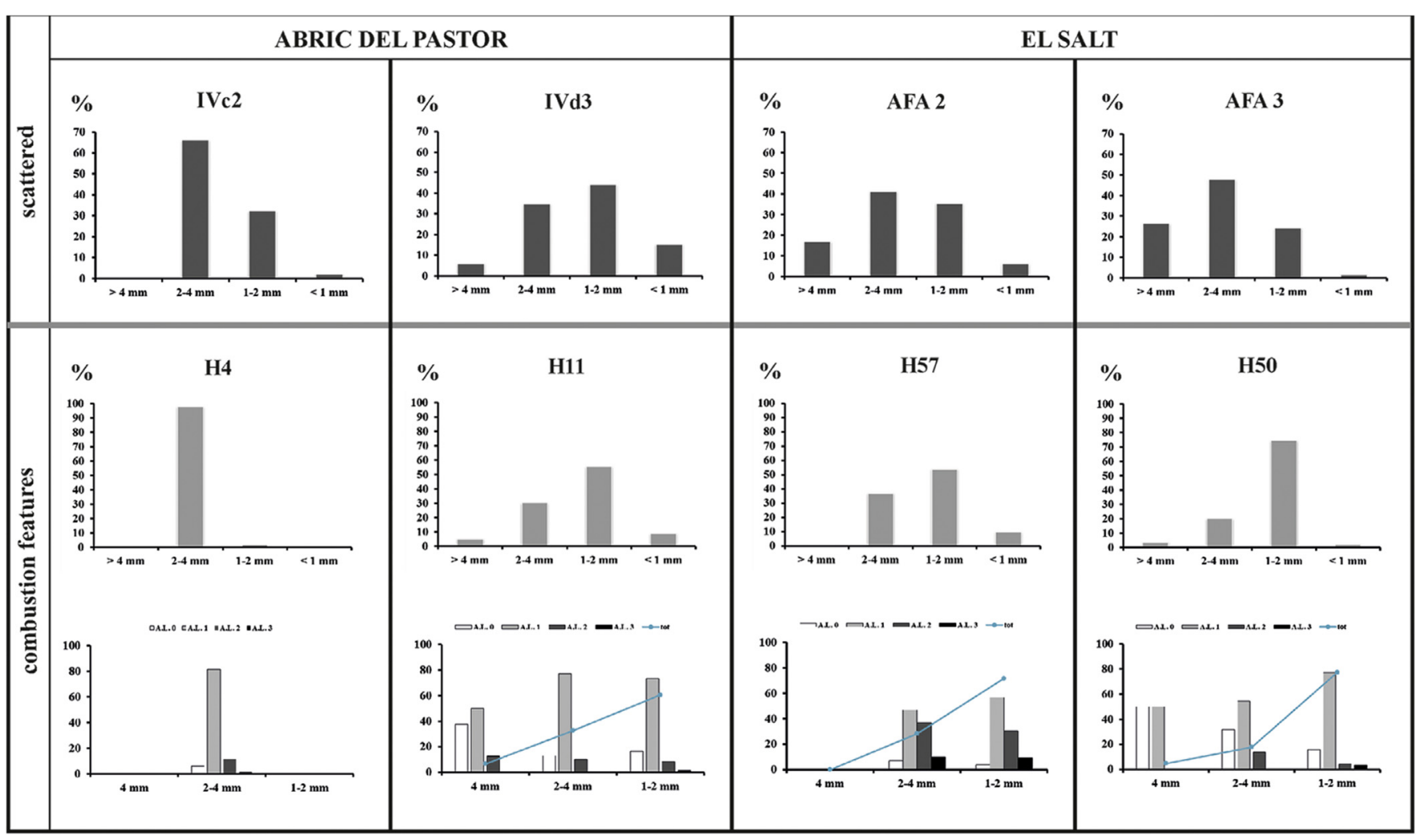

Fig. 3. Charcoal fragmentation from the combustion features and the scattered assemblages.

intermediate size categories (2-4 $\mathrm{mm}$ and 1-2 mm) (Fig. 3). Low percentages $(6-12 \%)$ corresponded to larger $(>4 \mathrm{~mm})$ or smaller $(<1 \mathrm{~mm})$ fragments. This proportion of size categories is consistent with those observed in the scattered anthracological assemblages, typical of post-combustion processes (Chrzazvez et al., 2014; Théry-Parisot et al., 2010, 2016). With a predominance of 2-4 mm size groups, hearth $\mathrm{H} 4$ from Abric del Pastor contained fewer small-charcoal fragments than $\mathrm{H} 11$ which is stratigraphically located below this feature. Due to their stratigraphical position, the underrepresentation of small size-classes within feature $\mathrm{H} 4$ may be due to post-depositional percolation of small charcoal fragments by natural and/or anthropogenic processes resulting in a more balanced size profile in H11.

\subsection{Quantifying the wood decay features on charcoal}

\subsubsection{Conifers}

Although the saturation curves from our combustion features show that the minimum number of charcoal fragments was probably not reached, the main tendencies are already perceptible after the study of 70-80 charcoals (Fig. 4). Thus, the stabilisation of the curves from features $\mathrm{H} 4, \mathrm{H} 50$ and $\mathrm{H} 57$-and to a lesser extent H4contribute to the consideration of our samples as statistically representative of the results provided here. Comparing the calculated Ais for the combustion features, all are clustered around 0.35, with the exception of $\mathrm{H} 57$ which was considerably higher $(A i=0.46)$ (Fig. 5a). According to the Ais obtained, our results can be attributed to two categories; on the one hand, combustion features $\mathrm{H} 4, \mathrm{H} 11$ and $\mathrm{H} 50$ had similar Ai's ranging from 0.3 to 0.35 which are experimentally characteristics of dead wood gathering with low and medium values of biodegradation (Fig. 5b). On the other hand, feature H57 was very close to the division between dead and rotting wood in the experimental studies (Fig. 5b). This last observation was confirmed by the examination of the A.L. frequency values, with feature H57 presenting degradation patterns similar to the experimental half-rotten wood profile (HRST). Hence, it shares microscopic characteristics with the assemblages defined as dead wood, although with fewer unaltered charcoals and higher values for A.L. 2 and 3 (Fig. 2c). It is noticeable that the A.L. percentages of features $\mathrm{H} 4, \mathrm{H} 11$ and $\mathrm{H} 50$ show an appreciable imbalance with the experimental batches (Fig. 2c): values of A.L. 0 ranging between 7 and 20\% would be representative of rotten wood, whereas values of A.L. 2 from 5 to $11 \%$ would be found in healthy to healthy-looking dead wood and the extremely low values of A.L. $3(0-3 \%)$ would be exclusive to the use of seasoned green wood. Although some studies point out to the existence of different resistance to fungal activity between conifers (e.g. Tumen et al., 2013) this imbalance between the A.L. frequency values from these three features and the experimental profiles is apparently independent of the conifer used as fuel, i. e. junipers for features $\mathrm{H} 4$ $-\mathrm{H} 11$ and scots pine for feature H50. In this sense, the values obtained for A.L. 1 (ranging from 72 to $81 \%$ ) are unusual for any kind of experimental profile, as the highest percentages of this A.L. correspond to dead wood in a medium state of decay and do not exceed $45 \%$. According to the different experimental profiles, it is to note that a mixture of wood under different states (i.e., dead and sound; dead and rotten; sound and rotten) cannot explain the high A.L. 1 percentages. Moreover, given the fact that the effort-yield curves are quite stable, it seems unlikely that these unusual profiles would be linked to an insufficient number of studied fragments. Hence, two hypotheses can be proposed in order to explain the unusual profiles of H4, H11 and H50: 1) Juniperus, the dominant taxon identified in $\mathrm{H} 4$ and $\mathrm{H} 11$, presents completely different degradation patterns due to its higher resistance to fungi, which doesn't explain the similar profile obtained for $\mathrm{H} 50$ or 2) the overrepresentation of A.L. 1 is due to a significant loss in the other A.L. categories. In this 


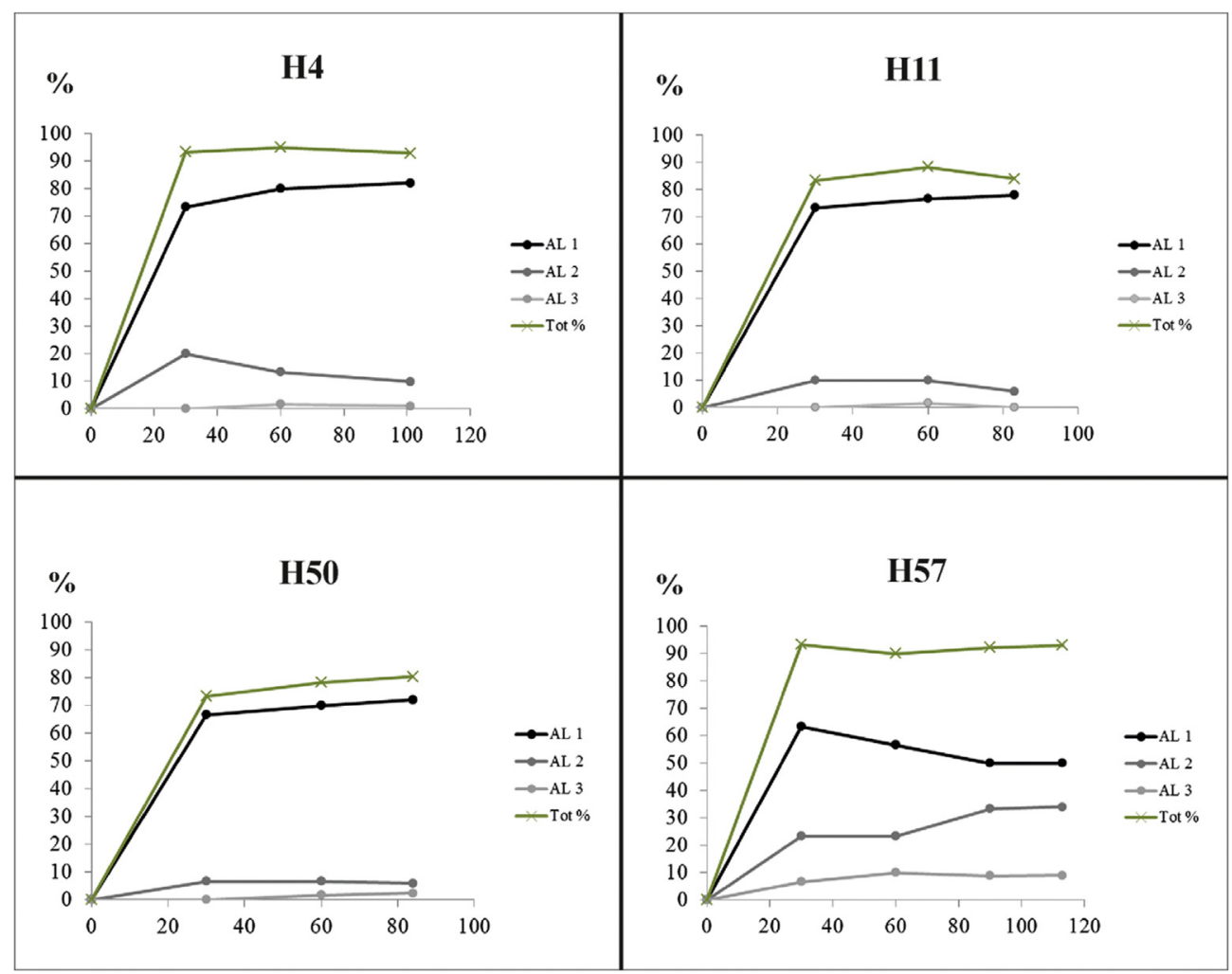

Fig. 4. Saturation curves with the quantification of the different A.L. composing the samples.

scenario, the disappearance of non-degraded charcoals (A.L. 0) would point towards the use of sound wood whereas the disappearance of degraded charcoals (A.L. 2 and 3) would imply that the wood used presented initially a higher alteration degree.

\subsubsection{Angiosperms}

Despite being less abundant than conifers (cf. Table 1), the results for angiosperms are characterized by a low percentage of unaltered charcoals (8-30\%) compared to the altered ones reaching $70-90 \%$ of the angiosperm assemblages (Table 2). Although no referential is yet available, these data strongly suggest the use of dead wood even if we cannot yet relate these observations to a defined macroscopic state (e.g. dead or decayed wood).

\section{Towards the characterization of firewood gathering among Neanderthal groups}

\subsection{Post-depositional processes: a differential preservation of charcoal?}

The A.L. quantification analysis shows a great proximity of feature H57 with experiment HRST (Pinus sylvestris half-rotten wood) while a significant imbalance between features H4, H11, $\mathrm{H} 50$ and experimental dead wood batches is observed (Fig. 5b and c). Indeed, experiments have shown that dead wood is characterized by the predominance of A.L. 1 (25-42\%), a significant presence of A.L. 2 (15-22\%) and low percentages for A.L. 3 (1-8\%) whereas our results for these three features show an overrepresentation of A.L. 1 and a much lesser presence of A.L. 2/3 charcoals. Even though fragmentation analyses per se do not allow us to assess taphonomic issues, their combination with the quantitative study of fungal degradation patterns provides significant observations regarding the modalities of charcoal preservation. Taking into account that previous studies have demonstrated the effect of mechanical processes on charcoal considering the state of the wood before combustion (Chrzazvez et al., 2014; Théry-Parisot et al., 2010), this unusual profile not reproduced in the experimental batches might reflect post-depositional processes affecting the higher degraded charcoals which would also correspond to the least resistant to mechanical processes, resulting in an overrepresentation of A.L. 1 charcoals (low alteration intensity) compared to the lower frequencies of A.L.2/3 charcoal remains (high alteration intensities). Indeed, recent data suggest that wood charcoal with signs of decay (i.e. presence of cell wall weakness, boreholes, hyphae, deformation of the cell morphology) is susceptible to be damaged during water processing, and as a result, can be underrepresented in the charcoal assemblages recovered with flotation (Arranz-Otaegui, 2016). Concerning the contribution of the available size-classes to each A.L., a general distribution of "big"-charcoal fragments ( $>4 \mathrm{~mm}$ and $2-4 \mathrm{~mm}$ ) from these three features within A.L. $0-1$ is noticeable while feature $\mathrm{H} 57$ shows higher percentages of $2-4 \mathrm{~mm}$ and 1-2 mm charcoals from A.L. 2-3 (cf. Fig. 3). If the loss of A.L. 2/3 charcoals due to post-depositional processes as well as the relatively low frequencies of A.L.0 are taken into consideration, a similar profile to experiment HRST or, at least, a higher amount of degraded wood fragments would be expected for features H4, H11 and $\mathrm{H} 50$ (low frequencies of A.L. $0-1$ and predominance of A.L. $2-3$ ). Thus, the initial charcoal composition of these three features could have been similar to that of H57 (or even to that of experimental features R1-R2 in what regards H4) showing only feature H57 comparable values of altered/non-altered charcoals to those from experimental batches (cf. Fig. 2c). Hence, the method suggested (combination of fragmentation with fungal decay patterns analyses) has pointed out to differential preservation issues with feature H57 as an exceptionally well-preserved charcoal deposit which allow us to gain further insight into fire-related social 


\section{a. Proportions of A.L.}

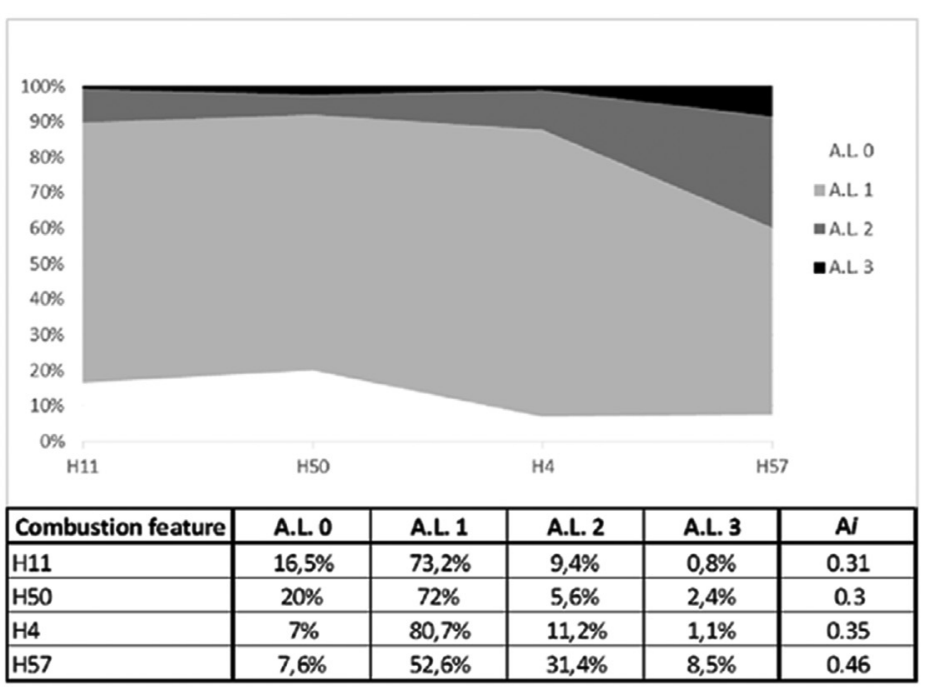

\section{b. Corresponding statistical groups}

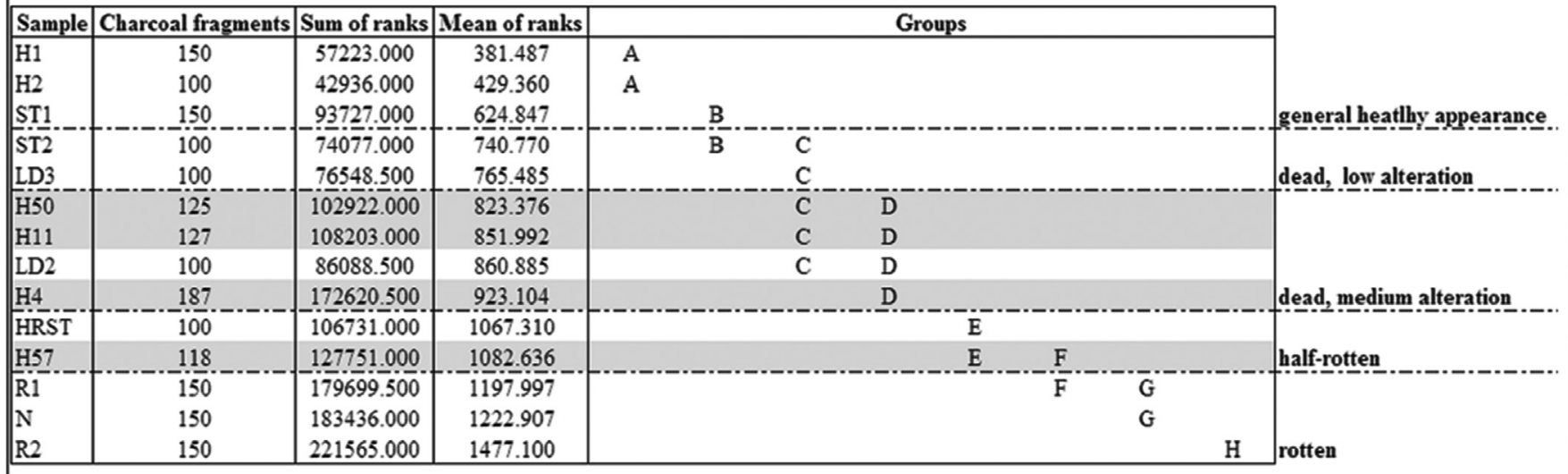

\section{c. Statistical differences}

\begin{tabular}{|c|c|c|c|c|c|}
\hline Archaeological samples & Description & $\mathrm{H} 11$ & $\mathrm{H} 50$ & $\mathrm{H} 4$ & $\mathrm{H} 57$ \\
\hline (2) & Abric del Pastor, unit IVc2 & No & No & No & Yes \\
\hline H11 & Abric del Pastor, unit IVd3 & No & No & No & Yes \\
\hline $\mathrm{H} 50$ & E1 Salt, AFA 3 & No & No & No & Yes \\
\hline $\mathrm{H} 57$ & E1 Salt, AFA 2 & Yes & Yes & Yes & Non \\
\hline Experimental samples & Macroscopic state of the wood & & & & \\
\hline $\mathrm{H} 1$ & Healthy & Yes & Yes & Yes & Yes \\
\hline $\mathrm{H} 2$ & & Yes & Yes & Yes & Yes \\
\hline ST1 & General healthy appearance, locally grayish, & Yes & Yes & Yes & Yes \\
\hline LD3 & $\begin{array}{l}\text { most of the bark still present }\end{array}$ & No & No & Yes & Yes \\
\hline ST2 & & No & No & Yes & Yes \\
\hline LD2 & Medium decay, greyish, mostly without bark & No & No & No & Yes \\
\hline HRST & Half-rotten, no bark, beginning to crumble & Yes & Yes & Yes & No \\
\hline R1 & Rotten, reddish & Yes & Yes & Yes & No \\
\hline $\mathrm{R} 2$ & Rotten, crumbling & Yes & Yes & Yes & Yes \\
\hline Ethnographic sample (Evenk hide-smoking hearth) & Macroscopic state of the wood & & & & \\
\hline $\mathrm{N}$ & Dark red, rotten, crumbling & Yes & Yes & Yes & Yes \\
\hline
\end{tabular}

Fig. 5. Quantification and statistical analysis of the results. 
practices.

\subsection{Palaeoeconomical data from Middle Palaeolithic combustion features}

According to the experimental results obtained by Henry and Théry-Parisot (2014), a low index $(<0.15)$ corresponds to healthy wood assemblages. Medium values (from 0.2 to 0.5 ) point out to dead wood batches, whereas values higher than 0.5 characterize rotten wood assemblages. Even though we might be facing charcoal preservation issues, probably linked to the disappearance of the higher altered fragments, the Ai's obtained from the four combustion features analysed are all included in the same category, excluding the use of sound wood and suggesting dead wood gathering strategies by Neanderthal groups according to its statistical correspondence with previous studies (Fig. 5b and c). Furthermore, it should be emphasized that especially in feature $\mathrm{H} 11$ the high taxonomic diversity was especially remarkable (minimum of six taxa). According to this, it can be suggested that dead wood of some frequent species could have accumulated in the ravine where Abric del Pastor is located, where they were indiscriminately gathered. Thus, the unusual taxonomic diversity of some archaeological combustion features could be additional evidence of firewood collection oriented towards specific states of the wood instead of species. In addition, in agreement with its higher values of biodegradation, gathering of fallen dead wood on the ground could be suggested, at least in what regards feature H57 and, possibly, in $\mathrm{H} 4$ (cf. Fig. 5b).

Anatomical alterations in wood charcoal have been detected in other hunter-gatherer contexts suggesting the preferential use of dead wood: Grotta di Fumane (Chrzavzez, 2006); Pataud, Castanet and Combette (Théry-Parisot, 2001; Théry-Parisot and Texier, 2006) or Abric Romani (Allué et al., 2016). Although direct comparison of our quantitative data from Abric del Pastor and El Salt with the results from other Middle Palaeolithic sites is difficult, the global percentages of degraded charcoals from all of them are close to $70-80 \%$ while the values for dead wood experimental batches are $35-70 \%$ and for rotten/half-rotten experimental batches range between 80 and 90\% (Henry and Théry-Parisot, 2014). These archaeological examples, along with Abric del Pastor and El Salt in Eastern Iberia, highlight the importance of dead wood as a key resource for firewood during the Palaeolithic and the Mesolithic. Although some researchers conceive dead wood gathering as an opportunistic behaviour the palaeoeconomical approach adopted here points at non-random firewood collection, but geared towards specific needs by Neanderthal groups. In addition, the existence of firewood collection strategies based on dead wood selection is not incompatible with the preferential use of one or two taxa which are usually the most frequent in the surroundings. Indeed, the abundance of Pinus nigra-sylvestris in the anthracological record from the combustion structures of El Salt could mirror its high rates of dead wood production, providing easily available twigs and branches (Costa et al., 2005). The preferential use of degraded wood by Neanderthal groups could be firstly related with the huntergatherer way of life which is based on territorial mobility and seasonal occupation of sites. This implies that dead/decayed wood would have been a valuable resource, easily accessible, readily useable, inexpensive to gather and capable of meeting all the group's fuel needs. The abundance or the scarcity of dead wood in the surroundings could have important implications regarding the firewood catchment area (short gathering distances with abundant dead wood and catchment area enlargement when it became scarce) and the duration of human occupations (short occupation events could prevent dead wood exhaustion). Additionally, due to its fuel properties (e.g. low thermal balance, low thermal output) preferential use of degraded wood could be related to specific activities (e.g. cooking, roasting) or to smoke production for repelling mosquitoes and flies, protection against predators and/or greater visibility from afar by other human groups.

It is also worth noting that feature H57 has provided meaningful palaeoeconomic inferences regarding firewood collection criteria and the relationship established between the presence of charcoal remains and charred seeds within the structure. Indeed, within the ashy layer of this hearth a total of 253 charred seed fragments of cf. Acer sp. were preserved together with firewood remains mainly composed of Acer sp. and Pinus nigra-sylvestris. Although our initial hypothesis was based on the use of maple wood for fuel with the seeds still inserted on the branches, our recording method for angiosperms based on the presence/absence of fungal decay features on charcoal allowed us to observe a higher proportion of degraded maple charcoals (A.L. $1=90 \%$ ) than non-degraded ones (A.L. $0=10 \%$ ). These data, together with the carpological remains, could bring into question if maple wood and fruits gathering functioned as related or non-related activities i.e., on the one hand, the carpological remains would provide evidence for the probable use of maple green wood with the seeds still inserted in the branches, keeping in mind that most of their seeds fall from the tree to the ground due to wind action; whereas on the other hand, the greater frequencies of degraded maple charcoals could point out to maple dead wood gathering, highlighting two episodes instead of one i.e., 1) ripe fruits gathering and 2) dead maple wood acquisition, leading us to consider these episodes as independent activities.

\subsection{H57: the earliest evidence of a smoking hearth?}

A hypothesis can be put forward for the firewood use in this hearth as follows: gathering of dead, mostly degraded black-scots pine together with the collection of dead maple branches at, at least, an incipient state of biodegradation (Fig. 6). Our inference about degraded wood selection may point towards a smoking related function as in this state of decay the wood tends to absorb soil and atmospheric moisture easily which makes it burn slowlier producing smoke.

The aim of smoke production is difficult to define based on the anthracological evidence since it may have served several purposes i.e., the preservation of meat in view of a group migration, the treatment of hides, the repelling of mosquitoes or flies, among others. Ethnoarchaeological smoking hearths point out to several possible options according to environmental variations and cultural choices. In Siberia and Alaska, smoking of food is not usually carried out using conifers as it gives a bad taste and degrades the meat (Henry, 2011; Vaté and Beyries, 2007) although any species may be used for meat protection against flies (Henry, 2011). In contrast to this, riverside woods such as Salix (willow) or Populus (poplar) are most often used for fish smoking purposes (Alix and Brewster, 2004; Henry et al., 2009; Vaté and Beyries, 2007) while a wider range of taxa are often used among Karok groups (Western United States) for similar smoking functions (Schenk and Gifford, 1952). In hide-smoking hearths the use of very rotten conifers has been observed, showing that the state of the wood is just as important as the species itself (Brandišauskas, 2011; Henry and Théry-Parisot, 2014; Lavrillier, 2005; Skibo et al., 2007). Additionally, in ethnographic combustion features used to ward off insects (mosquitoes and flies) the fuel mostly consisted of green and/or rotten wood with the addition of moss, leaves and dead wood (Binford, 1967, 1980; Brandišauskas, 2011; Henry et al., 2009). In this way, taking into account the conformation of many Palaeolithic sites as hearthrelated accumulations (Vaquero and Pastó, 2001), the location of H57 very close to the rock shelter wall could be linked to other combustion features protecting the area against insects (cf. features 


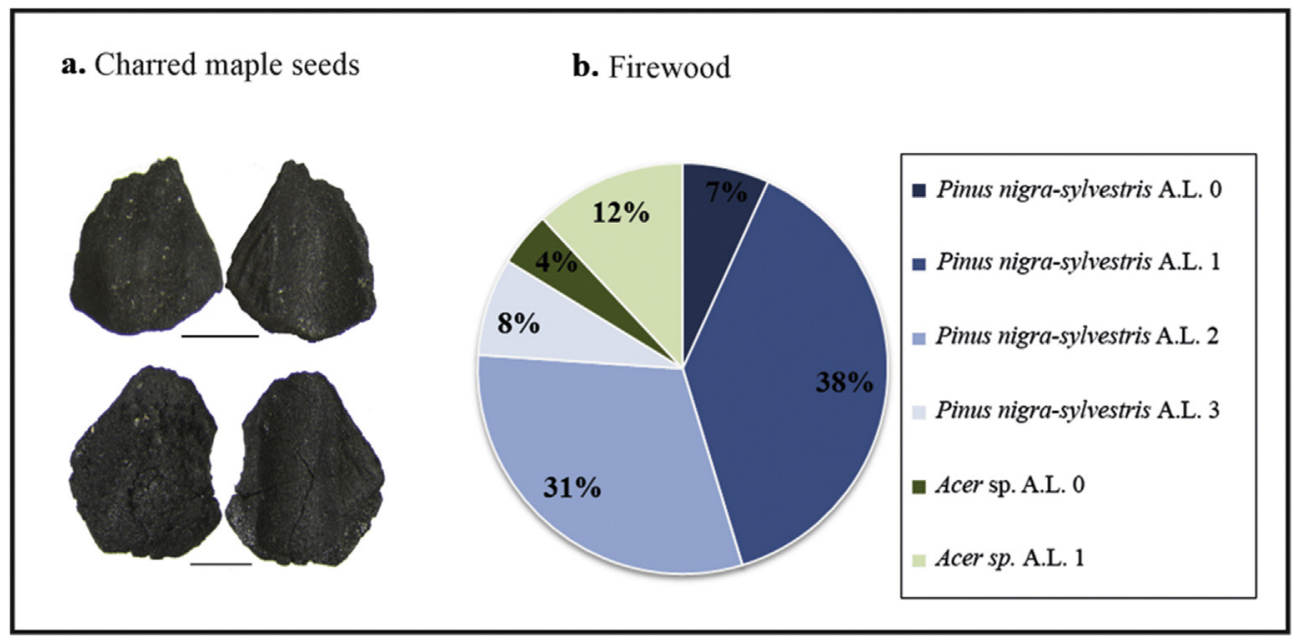

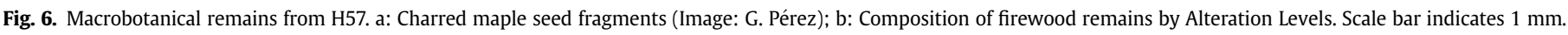

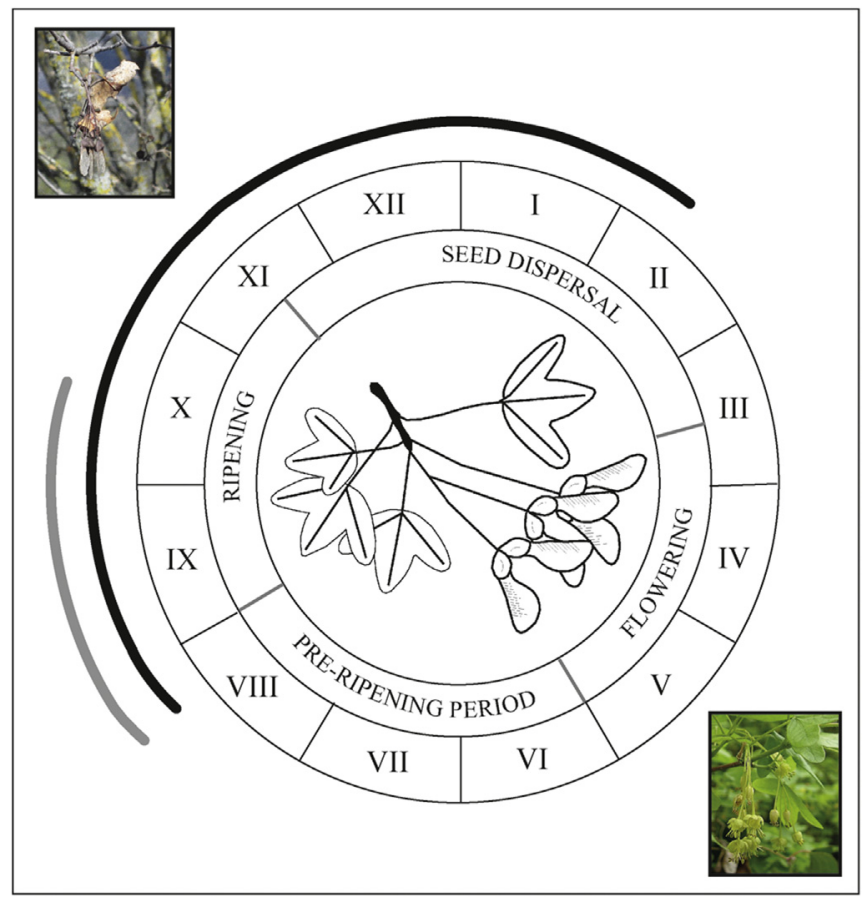

Fig. 7. Maple growth cycle: flowering, pre-ripening, ripening and seed dispersal. Roman numerals indicate months of the year. According to our data, different seasonal patterns can be suggested depending on the consideration of maple wood and fruits gathering as dependent activities (black thick line) or independent activities (grey thick line).

H44 or H45; see Vidal-Matutano, 2016a for the spatial location of combustion features).

\subsubsection{The presence of maple seeds: deliberate selection or fortuitous combustion by-product?}

Other possible functions for feature $\mathrm{H} 57$ could be remarked as seed roasting purposes resulting from a deliberate selection of maple fruits, as indicated above. According to this, the priority would have been to obtain embers rather than flames, which could explain the reduced nature of the ashy layer preserved (C. M. Hernández, pers. comm.). A short combustion event could have been responsible of an incomplete burning of the firewood allowing the preservation of a high amount of charcoal fragments along with the charred maple seeds.

Furthermore, the presence of these carpological remains could provide clues to the seasonal use of this hearth according to the growth cycle of maple (Fig. 7). In consonance with this, maple trees flower during spring (March-May), while after fertilization the seeds begin to develop during the summer (June-August). Ripening of the fruit on branches takes place in autumn (September-November) (Costa et al., 2005). These consist of two-seeded samaras, most of which fall from the tree due to the wind, while only a few remain attached until the end of winter. On this basis, it could be suggested that the occupation event related to combustion feature H57 may have taken place during the autumn-winter period given the number of ripe fruits which would have still been attached to the green branches during this season. Nevertheless, the important percentages of fungal degradation features observed on charcoal are not in accordance with the use of green maple fuel branches with the fruits still attached. Bearing this in mind, if maple wood and fruits gathering functioned as independent activities, then a more reduced seasonality pattern could be proposed on the basis of the best period to gather ripe fruits (vs. the maximum timeframe in which the seeds are attached to the branches), which would have taken place between late summer and early autumn). Thus, in order to obtain meaningful data on Neanderthal social practices, territorial management and seasonal activities, we should not consider straightforward the presence of carpological remains as fortuitous. Further multidisciplinary data from this combustion feature together with the analysis of the living surface remains is needed to get a better understanding of its function.

\section{Conclusions}

Our results have demonstrated the viability of the existing analytical methodologies for the observation of fungal degradation on Middle Palaeolithic combustion features taking into account some prerequisites needed to obtain significant palaeoeconomical data, where exhaustive micromorphological analyses together with the systematic sampling of charcoal remains constitute two of the main determining factors. Although charcoal fragments from Middle Palaeolithic combustion features are rarely preserved, saturation curves applied to our samples allowed to observe the main tendencies of the A.L. proportions after the study of 70-80 charcoals. The quantitative analysis of the A.L.s along with its 
comparison with the experimental assemblages constitutes a pioneering study in Middle Palaeolithic contexts contributing to the consideration of post-depositional processes that probably affected the higher degraded charcoals. Since not all species respond equally to fungal activity, further experimental studies focusing on other taxa (e. g. Juniperus sp. and Acer sp.) are indispensable to observe the way fungi invest and modify ligneous structures. Hence, the double approach used here (state of the wood - fragmentation degree) highly contributes to our understanding of firewood gathering practices and taphonomy, as decayed wood collection may have a direct impact on charcoal preservation. In this sense, further micromorphological data from these sites will strongly contribute to the identification of post-depositional factors affecting the combustion structures. The microscopic characterization of fungal decay patterns has enabled the identification of nuances between the content of the combustion features, which would not have been possible by using only classic anthracological methods (botanical identification). We have provided data that suggest the use of degraded wood by Neanderthal groups in Eastern Iberia, a practice also observed in other hunter-gatherer sites from elsewhere and from different time periods. Thus, our results have significant implications for the interpretation of firewood management which was traditionally defined as an opportunistic activity based on non-specific selection criteria. Since dead wood is often accessible and available in the surroundings it probably satisfied the bulk of firewood needs as it is perfectly suited to the hunter-gatherer way of life (brief, repeated and probably seasonal occupation of sites). Accordingly, degraded wood selection by Neanderthals, which probably focused on wood lying on the ground, would be related to obtaining a valuable resource without involving great acquisition effort. Finally, the microscopic observation of fungal decay features on charcoal from combustion structure $\mathrm{H} 57$ has also allowed inferring smoking related functions, which would be the earliest archaeological evidence of it. Further research in charcoal analysis from a palaeoeconomical perspective combining the recognition of fungal decay features and the fragmentation degree analysis will contribute meaningful insights into the nature of the firewood used by Neanderthal groups as well as the discussion of the interrelations between different plant acquisition systems (firewood and fruits). Finally, although our results constitute a pilot study without serving as a representation of Middle Palaeolithic contexts, it enables the feasibility of the existing methods to provide significant palaeoeconomical data from suitable concentrated charcoal assemblages. The increasing application of these methods in other Middle Palaeolithic contexts will provide a more holistic understanding of firewood use and management by Neanderthal groups.

\section{Acknowledgements}

This work was carried out with the financial support of a VALi+d pre-doctoral grant (ACIF/2013/260) and a research stay at the CEPAM (UMR 7264 CNRS) (BEFPI/2015/003). Archaeological research at both sites was funded under the Spanish Government projects HAR2012-32703 and HAR2015-68321-P (MICINN-FEDER) and Direcció General de Cultura (Conselleria d'Educació, Cultura i Esports, Generalitat Valenciana). We thank the El Salt and El Abric del Pastor team members for their help with field sampling tasks and Guillem Pérez for the identification of carpological remains from El Salt. We are also thankful to the anonymous reviewers who helped to improve the earlier version of this paper.

\section{References}

Cave (Israel) through high resolution study of prehistoric combustion features: evidence from phytoliths and thin sections. Quat. Int. 247, 278-293.

Alix, C., Brewster, K., 2004. Not all driftwood is created equal: wood use and value along the Yukon and Kuskowim Rivers, Alaska. Alaska J. Anthropol. 2, 48-65.

Allué, E., Cabanes, D., Solé, A., Sala, R., 2012. Hearth functioning and forest resource exploitation based on the archeobotanical assemblage from Level J. In: Carbonell, E. (Ed.), High Resolution Archaeology and Neanderthal Behavior: Time and Space in Level J of Abric Romaní. Springer, Capellades, Spain, pp. 373-385.

Allué, E., Solé, A., Burguet-Coca, A., 2016. Fuel exploitation among Neanderthals based on the anthracological record from Abric Romaní (Capellades, NE Spain). Quat. Int. http://dx.doi.org/10.1016/j.quaint.2015.12.046.

Arranz-Otaegui, A., 2016. Evaluating the impact of water flotation and the state of the wood in archaeological wood charcoal remains: implication for the reconstruction of past vegetation and identification of firewood gathering strategies at Tell Qarassa North (south Siria). Quat. Int. http://dx.doi.org/ 10.1016/j.quaint.2016.06.03.

Badal, E., 1992. L'anthracologie préhistorique: à propos de certains problèmes méthodologiques. Bull. la Soc. Bot. Fr. 139, 167-189.

Badal, E., 1988. Resultados metodológicos del estudio antracológico de la Cova de les Cendres (Alicante, España). In: Actes du colloque Paleoecología e Arqueología, Vilanova de Familaçao (Portugal), pp. 57-70.

Badal, E., Carrión, Y., 2001. Del Glaciar al Interglaciar: los paisajes vegetales a partir de los restos carbonizados hallados en las cuevas de Alicante. In: Villaverde, V. (Ed.), De Neandertales a Cromañones: El inicio del poblamiento en las tierras valencianas. Servei de Publicacions, Universitat de València, pp. 21-40.

Badal, E., Heinz, C., 1991. Méthodes utilisées en Anthracologie pour l'étude de sites préhistoriques. BAR Int. Ser. 573, 17-47.

Badal, E., Heinz, C., 1989. L'analyse anthracologique des dépôts préhistoriques Pléistocène supérieur et Holocène: prélèvement et analyse des données. Bull. Fr. Paléobot. 11, 9-16.

Badal, E., Villaverde, V., Zilhão, J., 2012. Middle palaeolithic wood charcoal from three sites in south and west Iberia: biogeographic implications. In: Badal, E., Carrión, Y., Macías, M., Ntinou, M. (Eds.), Wood and Charcoal. Evidence for Human and Natural History. Saguntum-extra 13. Universitat de València, Valencia, pp. 13-24.

Baldrian, P., Valášková, V., 2008. Degradation of cellulose by basidiomycetous fungi FEMS Microbiol. Rev. 32, 501-521.

Binford, L.R., 1980. Willow smoke and dogs' tails: hunter-gatherer settlement systems and archaeological site formation. Am. Antiq. 45 (1), 4-20.

Binford, L.R., 1967. Smudge pits and hide smoking: the use of analogy in archaeological reasoning. Am. Antiq. 32, 1-12.

Blanchette, R.A., 1991. Delignification by wood-decay fungi. Annu. Rev. Phytopathol 29, 381-403.

Brandišauskas, D., 2011. Hide tanning and its use in Taiga: the case of the OrochenEvenki reindeer herders and hunters of Zabaikalye (East Siberia). J. Ethnol. Folkloristics 4, 97-114.

Carrión, Y., Badal, E., 2004. La presencia de hongos e insectos xilófagos en el carbón arqueológico. Propuestas de interpretación. In: Martín Calleja, J., Feliu Ortega, M.J., Edreira Sánchez, M. del C. (Eds.), Avances en Arqueometría. Servicio de Publicaciones de la Universidad de Cádiz y Ayuntamiento del Puerto de Santa María, Cádiz, pp. 98-106.

Chabal, L., 1997. Forêts et sociétés en Languedoc (Néolithique final, Antiquité tardive): l'anthracologie, méthode et paléoécologie. Editions de la Maison des sciences de l'homme.

Chabal, L., 1992. La représentativité paléoécologique des charbons de bois archéologiques issus du bois de feu. Bull. la Soc. Bot. Fr. 139, 213-236.

Chabal, L., 1988. Pourquoi et comment prélever les charbons de bois pour la période antique: les méthodes utilisées sur le site de Lattes (Hérault). Lattara 1, $187-222$.

Chrzavzez, J., 2006. Collecte du bois de feu et paleoenvironnements au Paleolithique. Apport méthodologique et étude de cas: la grotte de Fumane dans les pré-Alpes italiannes. Mémoire de Master II. Université de Paris I PanthéonSorbonne.

Chrzazvez, J., Henry, A., Théry-Parisot, I., 2011. Identificando estrategias de adquisición del combustible leñoso en antracología: ¿puede contribuir la experimentación a determinar el calibre de los carbones en contexto arqueológico? In: Morgado, A., Baena, J., García, D. (Eds.), La Investigación Experimental Aplicada a La Arqueología. Universidad de Granada, pp. 205-211.

Chrzazvez, J., Théry-Parisot, I., Fiorucci, G., Terral, J.-F., Thibaut, B., 2014. Impact of post-depositional processes on charcoal fragmentation and archaeobotanical implications: experimental approach combining charcoal analysis and biomechanics. J. Archaeol. Sci. 44, 30-42.

Costa, M., Morla, C., Sainz (Eds.), 2005. Los Bosques ibéricos: Una interpretación geobotánica. Editorial Planeta, Barcelona.

Dufraisse, A., 2006. Charcoal anatomy potential, wood diameter and radial growth In: Charcoal Analysis: New Analytical Tools and Methods for Archaeology. Papers from the Table-Ronde Held in Basel 2004. BAR International Series, pp. 47-59.

Figueiral, I., 1992. Méthodes en anthracologie: étude de sites du Bronze final et de l'âge du fer du nord-ouest du Portugal. Bull. la Soc. Bot. Fr. 139, 191-204.

Galván, B., Hernández, C.M., Mallol, C., Mercier, N., Sistiaga, A., Soler, V., 2014. New evidence of early Neanderthal disappearance in the iberian peninsula. J. Hum. Evol. 75, 16-27.

Garralda, M.D., Galván, B., Hernández, C.M., Mallol, C., Gómez, J.A., Maureille, B. 
2014. Neanderthals from el Salt (Alcoy, Spain) in the context of the latest middle palaeolithic populations from the southeast of the iberian peninsula. J. Hum. Evol. 75, 1-15.

Goldberg, P., Dibble, H., Berna, F., Sandgathe, D., McPherron, S.J., Turq, A., 2012. New evidence on Neandertal use of fire: examples from Roc de Marsal and Pech de l’Azé IV. Quat. Int. 247, 325-340.

Henry, A., 2011. Paléoenvironnement et gestion du bois de feu au Mésolithique dans le sud-ouest de la France: anthracologie, ethno-archéologie et expérimentation. Unpublished Doctoral Dissertation. Université Nice Sophia Antipolis.

Henry, A., Théry-Parisot, I., 2014. From Evenk campfires to prehistoric hearths: charcoal analysis as a tool for identifying the use of rotten wood as fuel. J. Archaeol. Sci. 52, 321-336.

Henry, A., Théry-Parisot, I., Voronkova, E., 2009. La gestion du bois de feu en forêt boréale: problématique archéo-anthracologique et étude d'un cas ethnographique (Région de l'Amour, Sibérie). In: Proceedings of the XV World Congress. BAR International Series, pp. 17-37.

Hernández, C.M., Galván, B., Mallol, C., Machado, J., Molina, F.J., Pérez, L.J., Morales, J.V., Sanchis, A., Vidal-Matutano, P., Rodríguez, Á., 2014. El Abric del Pastor en el poblamiento neandertal de los Valles de Alcoy, Alicante (España). In: Sala, R. (Ed.), Los cazadores recolectores del Pleistoceno y del Holoceno en Iberia y el Estrecho de Gibraltar: Estado actual del conocimiento del registro arqueológico. Universidad de Burgos y Fundación Atapuerca, pp. 319-323.

Jacquiot, C., Trenard, Y., Dirol, D., 1973. Atlas d'anatomie des bois des angiosperms (Essences feuillues). Centre Technique du Bois, Paris.

Lavrillier, A., 2005. Nomadisme et adaptations sédentaires chez les Évenks de Sibérie postsoviétique: «jouer» pour vivre avec et sans chamanes. École Pratique des Hautes Études, Paris.

Leonowicz, A., Matuszewska, A., Luterek, J., Ziegenhagen, D., WojtaśWasilewska, M., Cho, N.-S., Hofrichter, M., Rogalski, J., 1999. Biodegradation of lignin by white rot fungi. Fungal Genet. Biol. 27, 175-185.

Machado, J., Hernández, C.M., Mallol, C., Galván, B., 2013. Lithic production, site formation and Middle Palaeolithic palimpsest analysis: in search of human occupation episodes at Abric del Pastor Stratigraphic Unit IV (Alicante, Spain). J. Archaeol. Sci. 40, 2254-2273.

Machado, J., Molina, F.J., Hernández, C.M., Tarriño, A., Galván, B., 2016. Using lithic assemblage formation to approach middle palaeolithic settlement dynamics: el Salt stratigraphic unit X (Alicante, Spain). Archaeol. Anthropol. Sci. http:// dx.doi.org/10.1007/s12520-016-0318-z.

Machado, J., Pérez, L., 2015. Temporal frameworks to approach human behaviour concealed in Middle Palaeolithic palimpsests: a high-resolution example from El Salt Stratigraphic Unit X (Alicante, Spain). Quat. Int. http://dx.doi.org/10.1016/ j.quaint.2015.11.050.

Mallol, C., Hernández, C.M., Cabanes, D., Machado, J., Sistiaga, A., Pérez, L., Galván, B. 2013a. Human actions performed on simple combustion structures: an experimental approach to the study of Middle Palaeolithic fire. Quat. Int. 315, 3-15.

Mallol, C., Hernández, C.M., Cabanes, D., Sistiaga, A., Machado, J., Rodríguez, Á. Pérez, L., Galván, B., 2013b. The black layer of Middle Palaeolithic combustion structures. Interpretation and archaeostratigraphic implications. J. Archaeol. Sci. 40, 2515-2537.

Mallol, C., Marlowe, F.W., Wood, B.M., Porter, C.C., 2007. Earth, wind, and fire: ethnoarchaeological signals of Hadza fires. J. Archaeol. Sci. 34, 2035-2052.

Marguerie, D., Hunot, J.-Y., 2007. Charcoal analysis and dendrology: data from archaeological sites in north-western France. J. Archaeol. Sci. 34, 1417-1433.

Moskal del Hoyo, M., Wachowiak, M., Blanchette, R., 2010. Preservation of fungi in archaeological charcoal. J Archaeol. Sci. 37, 2106-2116.

Ntinou, M., Kyparissi-Apostolika, N., 2015. Local vegetation dynamics and human habitation from the last interglacial to the early Holocene at Theopetra cave, central Greece: the evidence from wood charcoal analysis. Veg. Hist. Archaeobot. 25 (2), 191-205.

Rodríguez-Cintas, Á., Cabanes, D., 2015. Phytolith and FTIR studies applied to combustion structures: the case of the middle paleolithic site of el Salt (Alcoy, Alicante). Quat. Int. http://dx.doi.org/10.1016/j.quaint.2015.09.043.
Schenk, S.M., Gifford, E.W., 1952. Karok Ethnobotany. Anthropological Records. University of California Press.

Schwarze, F.W.M.R., 2007. Wood decay under the microscope. Fungal Biol. Rev. 21 (4), 133-170.

Schweingruber, F.H., 1976. Anatomy of European Woods. Paul Haupt, Bern.

Sistiaga, A., Mallol, C., Galván, B., Summons, R.E., 2014. The Neanderthal meal: a new perspective using faecal biomarkers. PLoS One 9, e101045. http:// dx.doi.org/10.1371/journal.pone.0101045.

Skibo, J.M., Franzen, J.G., Drake, E.C., 2007. Smudge pits and hide smoking revisited. In: Skibo, J.M., Graves, M.W., Stark, M.T. (Eds.), Archaeological Anthropology: Perspectives on Method and Theory. University of Arizona Press, pp. 72-92.

Théry-Parisot, I., 2001. Economie des combustibles au Paléolithique. Expérimentation, anthracologie, taphonomie, D.D.A. CNRS-Editions.

Théry-Parisot, I., 1998. Économie des combustibles et paléoécologie en contexte glaciaire et périglaciaire, Paléolithique moyen et supérieur du sud de la France. Anthracologie, Expérimentation, Taphonomie. Unpublished Doctoral Dissertation. Université de Paris I Panthéon-Sorbonne.

Théry-Parisot, I., Chabal, L., Chrzavzez, J., 2010. Anthracology and taphonomy, from wood gathering to charcoal analysis. A review of the taphonomic processes modifying charcoal assemblages in archaeological contexts. Palaeogeogr. Palaeoclimatol. Palaeoecol. 291, 142-153.

Théry-Parisot, I., Gril, J., Vernet, J., Meignen, L., Maury, J., 1996. Coal used for fuel at two prehistoric sites in southern France: les Canalettes (Mousterian) and les usclades (Mesolithic). J. Archaeol. Sci. 23, 509-512.

Théry-Parisot, I., Henry, A., Chrzazvez, J., 2016. Contribuição da experimentação à compreensão das práticas sociais em antracologia: gestão e uso da lenha em sociedades pré-históricas. Cad. do LEPAARQ 13, 511-536.

Théry-Parisot, I., Meignen, L., 2000. Économie des combustibles (bois et lignite) dans l'abri moustérien des Canalettes. De l'expérimentation à la simulation des besoins énergétiques. Gall. Préhistoire 42, 45-55.

Théry-Parisot, I., Texier, P., 2006. L'utilisation du bois mort dans le site moustérien de la Combette (Vaucluse). Apport d'une approche morphométrique des charbons de bois à la définition des fonctions de site au Paléolithique. Bull. la Soc. Préhistorique Fr. 103, 453-463.

Thiébault, S., 1988. L’homme et le milieu végétal. Analyses anthracologiques de six gisements des Préalpes au Tardi- et au Postglaciaire. Doc. d'Archéologie Fr. 15, $7-110$.

Tumen, I., Eller, F.J., Clausen, C.A., Teel, J.A., 2013. Antifungal activity of heartwood extracts from three Juniperus species. BioResources 8 (1), 12-20.

Tuor, U., Winterhalter, K., Fiechter, A., 1995. Enzymes of white-rot fungi involved in lignin degradation and ecological determinants for wood decay. J. Biotechnol. $41,1-17$.

Vaquero, M., Pastó, I., 2001. The definition of spatial units in Middle Palaeolithic sites: the hearth-related assemblages. J. Archaeol. Sci. 28, 1209-1220.

Vaté, V., Beyries, S., 2007. Une ethnographie du feu chez les éleveurs de rennes du Nord-Est sibérien, in: les civilisations du renne d'hier et d'aujourd'hui. Approches Ethnohistoriques, Archéologiques et Anthropologiques. Éditions APDCA.

Vernet, J.-L., Badal, E., Grau, E. 1983. La végétation néolithique du sud-est de l'Espagne (Valencia, Alicante) d'après l'analyse anthracologique. Comptes rendus séances l'Académie Sci. 296, 669-672.

Vidal-Matutano, P., 2016a. Firewood and hearths: Middle Palaeolithic woody taxa distribution from El Salt, stratigraphic unit Xb (Eastern Iberia). Quat. Int. http:// dx.doi.org/10.1016/j.quaint.2016.07.040.

Vidal-Matutano, P., 2016b. Around the Fire: Landscape, Climate and Firewood Management in Hunter-gatherer Groups during the Middle Palaeolithic (Alicante, Spain). Unpublished Doctoral Dissertation. Universitat de València.

Vidal-Matutano, P., 2015. Evidència de recol-lecció de teix (Taxus baccata L.) pels grups neandertals de l'Abric del Pastor (Alcoi, Alacant). Recer. del Mus. d'Alcoi 24, 7-20.

Vidal-Matutano, P., Hernández, C.M., Galván, B., Mallol, C., 2015. Neanderthal firewood management: evidence from Stratigraphic Unit IV of Abric del Pastor (Eastern Iberia). Quat. Sci. Rev. 111, 81-93. 